Macfarlane Burnet (directoi, Walter and Eliza Hall Institute of Medical Research, Royal Melbourne Hospital), Dr. A. M. Clarke (Zoology Department, University of Melbourne), Mr. K. H. Clarke, Mr. H. A. S. van den Brenk, and Dr. J. H. Martin (convener) (Cancer Institute Board, Melbourne). A programme of four meetings for the year has been prepared, the intention of these first meetings being to cover fundamental concepts.

\section{Earthquakes in Persia}

BEGINNING on July 1 , a series of strong earthquakes has caused devastation in the Caspian Sea region, east and north-east of Teheran, in northern Persia. In Shahi the main government building and railway station were damaged. Polour and Olesefid, villages near Demavend, were destroyed. Damage occurred in Larijan, Sangechal, Firuzkuh, Veresk and other towns and villages, including Bandpay and Bulukamiri. In all, casualties may amount to 4,000 killed, 10,000 wounded and 100,000 homeless. Minor earthquakes occur frequently in the district, and major earthquakes have occurred in the district in the past. In 1802 Demavend and Mazandaran and seventy towns and villages in the region were destroyed. Semnan and Damghan suffered great damage. In 1810 an earthquake caused much destruction at Sari. Another earthquake occurred at Demavend in June 1811. Sir Arnold T. Wilson refers to an inscription on the Masjid-i Juma at Barfurush which states that it was destroyed by an earthquake in the reign of Fath Ali Shah. Aftershocks of the present series are still occurring and further news from the area is awaited.

\section{Earthquakes in Turkey}

Following the earthquakes at Fethiye less than a month ago and in Turkish Thrace on May 10, a severe earthquake shook the Bolu district on May 26 about 8.30 a.m. local time. This $(i P)$ was recorded at Kew Observatory at $06 \mathrm{~h} .38 \mathrm{~m} .52 \mathrm{~s}$. G.M.T. and the earthquake was of magnitude 7 . The shock was felt at Istanbul (Bolu is 200 miles north-east of Istanbul) and in many places nearer Bolu. At Bolu there was great destruction of property including the water-works, and in the neighbourhood of Lake Aband, a beautiful summer resort, several villages were utterly destroyed. Three islands appeared temporarily, but later disappeared, and on nearby land there were eracks wide enough for a man to walk in. A mosque collapsed in Chakmacilar village, south of Bolu, and two hundred houses were wrecked in the town of Seben. Altogether some sixty-six people were killed and more than seventy injured. The epicentre was near latitude $41^{\circ} \mathrm{N}$., longitude $31^{\circ} \mathrm{E}$. and the origin time $06 \mathrm{~h} .33 \mathrm{~m} .31 \mathrm{~s}$. G.M.T. ; there have been more than seven hundred aftershocks from the same (or very near) epicentre. Five people were killed in an earthquake in Bolu in February 1956. Most earthquakes in Turkey are of tectonic origin occasioned by 'Alpine' orogenic pressure. When this pressure builds up so as to exceed that required for rupture, slipping occurs usually along one or more of the ancient geological faults which abound. One such structural line muns through Mürefte, Izmit, Bolu and Gerede, and although earthquakes have their epicentres on it, it also has a great influence on relief and is both a very densely peopled zone and a corridor for communications. One of the greatest of Turkish earthquakes occurred on December 27, 1939, near
Erzincan. In this shock 16,629 buildings were completely destroyed, 9,599 partially destroyed, 23,148 people were killed and 8,029 injured (Nature, $145,13 ; 1940)$.

\section{Centenary of the Science Museum}

Durrng the past and present decades many museums have or will celebrate their centenaries. It was a happy thought of the late Dr. F. Sherwood Taylor, director of the Science Museum, London, that the centenary of that Museum, which falls this year, should be celebrated by the publication of a book. Through his untimely death in 1956 it was, however, left to the present director, Mr. T. C. S. Morrison-Scott, to implement the inspiration of his predecessor, and he is to be congratulated on the production of a readable and interesting volume, entitled "The Science Museum : the First Hundred Years" (pp. iv +85 . London: H.M. Stationery Office, 1957. 15s. net). The first part of the book gives a brief account of the history of the Museum from its inception in the Great Exhibition of 1851, its official opening to the public in 1857 in the 'Brompton Boilers', the opening of the east block by King George V in 1928, to the present day when the opening of the new Museum block is hopefully anticipated for the end of 1961 .

It is stressed that the policy of the Science Museum is directed, first, to enlarging our knowledge of the development of science from the earliest times, and secondly, to presenting that knowledge to the visitor. To these ends the Museum has gathered together a collection of historic scientific and technological objects unsurpassed anywhere in the world. The second and larger part of the book is thus appropriately devoted to short descriptions of twenty-one of these historic objects. These have been selected with discretion, and include the Wells Cathedral clock (1392), the original Davy lamp (1816), the Pyrophone (c. 1874), the Rolls-Royce motor-car (1905) and the Whittle turbo-jet engine and Gloster aircraft (194l). The book is amply illustrated and is another example of the imaginative format which now characterizes the publications of H.M. Stationery Office.

\section{Zoological Society of London}

Is 1951 an ambitious plan for rebuilding the Society's Gardens in Regent's Park and for further developments at Whipsnade were announced. The implementation of this plan had to be deferred until the necessary financial resources were available. The Council of the Zoological Society has now commissioned Sir Hugh Casson to prepare, in association with the Society's architect, an alternative sketch plan for the rebuilding of the Regent's Park Gardens. The ultimate object is to transform the Gardens in such a way that the north end of Regent's Park becomes a major feature of London, both architecturally and from the landscape point of view, as well as the finest zoological garden in Europe. 'This proposal is described in the annual report of the Zoological Society (Report of the Council and Auditors for 1956 . Pp. $63+4$ plates. London: 7oological Society of London, 1957), which. besides all the relevant details of finance, visitors, new acquisitions and publications, explains the arrangements which have been made with Granada Television, Ltd., for the installation of a television unit in the Society's gardens. 